\title{
RELIABILITY ANALYSIS OF A TWO SPAN FLOOR DESIGNED ACCORDING TO EUROCODE 5
}

\author{
E. N. Ogork ${ }^{1, *}$ and A. K. Nakore ${ }^{2}$ \\ 1DEPARTMENT OF CiVIL ENGINEERING, BAYERo UNIVERSITY KANO, KANO STATE. NIGERIA \\ 2 WURO AsSociates Limited, No 1, BUK RoAD, KANO, KANo STATE, NIGERIA \\ E-mail addresses: ${ }^{1}$ egbenguogork@yahoo.com, ${ }^{2}$ buddykays@yahoo.com
}

\begin{abstract}
:
This paper presents the structural reliability assessment of a two span timber floor of strength class D40 designed in accordance with Eurocode 5 (2004). The Structural analysis and design of the timber floor system was carried out using deterministic approach, considering both ultimate and serviceability limit states. Reliability analysis of the floor structural elements to ascertain its level of safety was carried out using first order reliability method (FORM) for the four modes of failure of bending shear, bearing and deflection. The reliability analysis involved investigation of the effects of variation of the applied dead to live load ratio and the cross sectional parameters of the floor. The results revealed that the deterministic design is satisfactory as limiting stresses and deflection were not exceeded. The primary floor joists had safety indices in shear and bending of 1.2 to 2.8 with decrease in dead to live load ratio and were below the recommended safety index of 3.8 specified in joint committee on structural safety (JCSS). The timber floor structural elements are more reliable in bearing, shear and deflection and critical in bending mode of failure. The section depth and span of floor elements are more sensitive in bending and deflection modes than shear and bearing modes.
\end{abstract}

Key words: Failure modes, Safety index, Reliability, Timber, Two span

\section{INTRODUCTION}

The unique characteristics and abundant supply of wood have made it the most desirable building material throughout history [1]. According to [2], the history of timber being used as a construction material can be traced back to when the human species first started to employ tools or even farther.Timber from well-managed forests is one of the most sustainable resources available and is one of the oldest known materials used in construction. Timber is used for many purposes in the construction industry. Its uses include; formwork for concrete, timber beam joists, columns, timber floors, scaffolds, roof trusses[2].Construction activities using vast quantities of locally available raw materials such as timber are major steps towards industrialization and economic independence for developing countries [3], [4]. Timber is a naturally occurring structural material obtained from trees, and trees that are characterized by having naked seeds and generally have needle-like leaves that are evergreen (such as conifers) are called softwoods, while hardwoods are generally broad-leaved (deciduous) trees, which often lose their leaves at the end of each growing season and have seeds inside a fruit. The cell structure of hardwoods is more complex than that of softwoods with thick-walled cells, called fibres, providing the structural support [5]. Most timber used in the building construction are softwoods, but in structures that require timber of high strength and durability, such as bridges and railway sleepers, hardwoods are especially used [6]. Timber as a natural material complements any landscape, whether blending naturally into the countryside or providing a contemporary striking design alongside modern architecture in our towns and cities. Afolayan and Adeyeye [7] noted the inherent advantages of timber that make it especially attractive in specific applications.

Timber floor is used in buildings, local ports decks and footbridges to provide platforms for walking [2]. A timber floor comprised of a series of joists closely spaced, floor boarding or decking applied on the top of the joists and ceiling linings underneath, if it is suspended. The distance between the centers of the joists is normally governed by the size of the decking and ceiling boards, joist span and other geometrical constraints. The size of the decking and ceiling boards allows convenient joist spacing's of $300 \mathrm{~mm}, 400 \mathrm{~mm}$ or $600 \mathrm{~mm}$ centre to centre. In addition, the most common floor decking in domestic dwellings and timber-framed 
buildings uses some form of wood-based panel products, such as chipboard or plywood [5].

One of the objectives of structural design is to fulfil certain performance criteria related to safety and serviceability of the structure. These performance criteria are usually formulated as limit states, which are mathematical description of the limits between performance and non-performance [8]. Probabilistic design is concerned with the probability that the structure will realize the functions assigned to it [9], [10]. Engineering design decisions are surrounded by uncertainties that result from the random nature of loading, strength and stiffness parameters, dimensions and geometrical imperfections as well as the load and resistance prediction models. The effect of such uncertainties is included in design by safety factors that are based on engineering judgment and previous experience with similar structure. Because safety involves a consideration of random variables and the realization of the limitations in design by the deterministic method, it is now generally accepted that the rational approach to the analysis of safety is with probabilistic models [11].

According to [3] and [8], the question of reliability is especially complicated for timber because of the large natural variability of the material. A significant element of uncertainty is also introduced through lack of information about the actual physical variability. They also noted that the variability of strength between elements is significantly larger than that for steel or reinforced concrete members. The coefficient of variation is of the order of $20-40 \%$, with higher values for brittle type of failure modes [8].

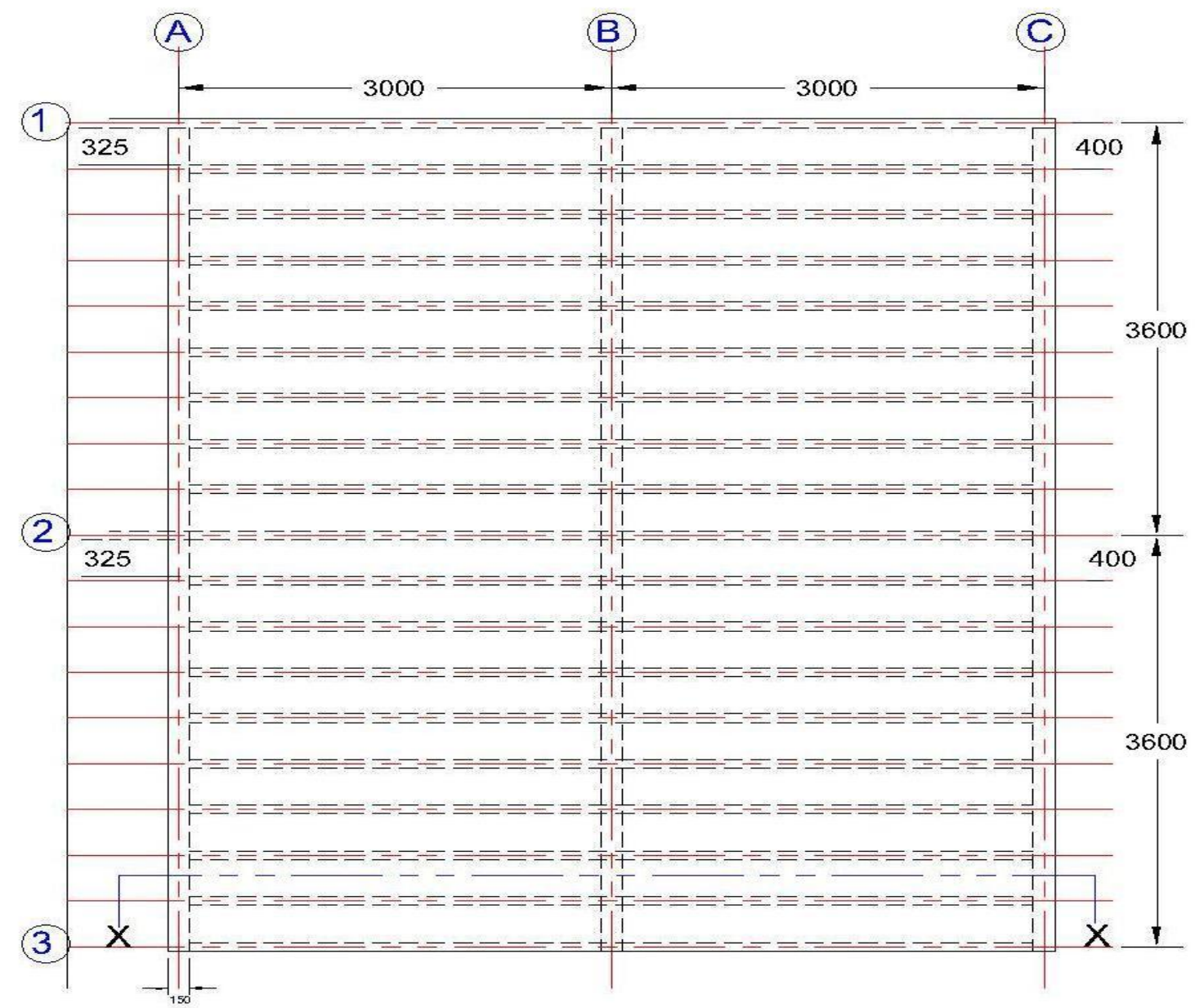

Plan

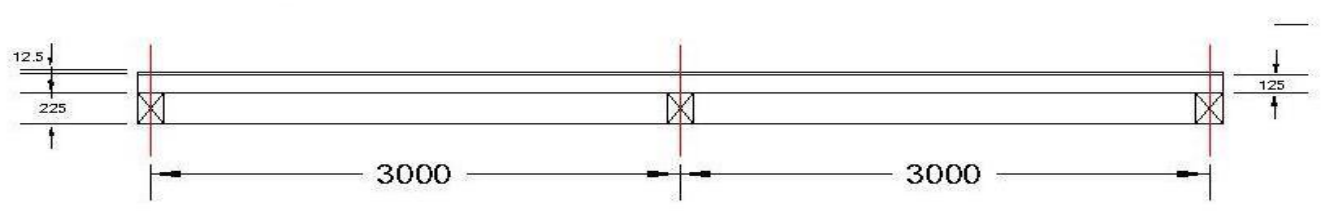

Section

Figure 1: Plan and section of timber floor (All dimensions in mm) 
This study presents the design and reliability analysis of a two span timber floor of a residential building in accordance with the Eurocode 5 (2004) [12] specification with a view to examining its safety level and economy.

\section{MATERIALS AND METHODS}

\subsection{Structural Analysis and Design of the two Span Timber Floor}

The timber floor selected for this study is a continuous floor over two spans in both directions of $3000 \mathrm{~mm}$ by $3600 \mathrm{~mm}$ (Figure 1). The platform is made up of timber planks supported on a system of joists (secondary joist) spaced at $400 \mathrm{~mm}$ from centre to centre. The secondary joists are supported by primary joist. A solid timber of grade class D40 is used. The floor is assumed to be a residential floor and functions in service class 1 in accordance with [12].

\subsubsection{Design of the floor deck}

Sizing of deck thickness: For floor with a uniformly distributed load the simplified method of analysis described in [12] was used. This is dictated by the allowable deflection, such that the structure has no adverse visual effect, functions as designed, no structural implication and structural services function satisfactorily. To prevent these effects from occurring due to excessive deflections as well as to meet functional and visual requirements, deflection has been specified to be not greater than span $/ 250$, $\mathrm{u}_{\text {net,fin }}$

Bending deflection for three or more spans,

$$
\omega_{\text {fin }}=\frac{\mathrm{wl}^{4}}{145 \mathrm{E}_{0, \text { mean }} \mathrm{I}} \times\left(1+\frac{0.96 \mathrm{E}_{0, \text { mean }} \mathrm{h}}{\mathrm{G}_{0, \text { mean }} \mathrm{l}}\right)
$$

Where $\left(1+\frac{0.96 \mathrm{E}_{0, \text { mean }} \mathrm{h}}{\mathrm{G}_{0, \text { mean }} \mathrm{l}}\right)$ is the Shear amplification factor Where $\omega_{\text {fin }}$ is the final deflection due to load, $u_{\text {net,fin }}$ is the net final deformation. $E_{0, \text { mean }}$ is mean modulus of elasticity, $G_{0 \text {,mean }}$ is shear modulus, $l$ is span, $h$ is the depth of the section, $w$ is the design load. Since the shear force in decks and slabs is insignificant, it can be ignored and the design is based on only the bending deflection [12].

\subsubsection{Design of the Secondary Joists}

Sizing of the secondary joists: The initial sizing of the section was carried out by limiting the deflection to the allowable deflection. A section was selected from the standard sizes of solid timber available based on the deflection limits. The section was loaded with the load from the deck and checked against bending, shear, bearing and deflection failure.

\subsubsection{Check for bending}

The condition that must be satisfied is $\sigma_{m, y, d} \leq f_{m, y, d}$ Where $\sigma_{m, y, d}$ is the design bending stress along the grain; $\mathrm{f}_{\mathrm{m}, \mathrm{y}, \mathrm{d}}$ is the design bending strength along the grain.

$$
\begin{gathered}
\sigma_{\mathrm{m}, \mathrm{y}, \mathrm{d}}=\frac{6 \mathrm{M}}{\mathrm{bh}^{2}} \\
\mathrm{f}_{\mathrm{m}, \mathrm{y}, \mathrm{d}}=\frac{\mathrm{f}_{\mathrm{m}, \mathrm{k}} \cdot \mathrm{K}_{\mathrm{mod}} \cdot \mathrm{K}_{\mathrm{sys}} \cdot \mathrm{K}_{\mathrm{h}}}{\gamma_{\mathrm{m}}}
\end{gathered}
$$

Where $b$ and $h$ are the breadth and depth of section, respectively. $\mathrm{M}$ is bending moment due to design load. $\mathrm{K}_{\text {mod }}$ is the modification factor for load duration and moisture content, $\mathrm{K}_{\text {sys }}$ is the system strength factor, $\mathrm{K}_{\mathrm{h}}$ is the modification factor for member size effect, $\gamma_{m}$ is a partial factor that takes into account the possibility of the characteristic value of a material or product property (for example, strength or stiffness) being less than the specified value, $f_{m, k}$ is the characteristic bending strength of the timber or, in the case of a wood-based structural product, the characteristic bending strength relating to the axis of bending being considered.

\subsubsection{Check for shear}

The condition that must be satisfied is that $\tau_{\mathrm{v}, \mathrm{d}} \leq \mathrm{f}_{\mathrm{v}, \mathrm{d}}$ Where $\tau_{\mathrm{v}, \mathrm{d}}$ is the design shear stress at the required level in the section. $f_{v, d}$ is the design shear strength for the condition being investigated.

For a beam without a notch,

$$
\begin{gathered}
\tau_{v, d}=\frac{3 V}{2 b h} \\
f_{v, d}=\frac{f_{v, k} \cdot K_{\text {mod }} \cdot K_{\text {sys }}}{\gamma_{m}}
\end{gathered}
$$

Where, $\mathrm{K}_{\mathrm{mod}}, \mathrm{K}_{\mathrm{sys}}, \gamma_{\mathrm{m}}$ are as described above and $\mathrm{f}_{\mathrm{v}, \mathrm{k}}$ is the characteristic shear strength of the timber used and $\mathrm{V}$ is the design shear force, $\mathrm{b}$ and $\mathrm{h}$ is as described in equation (2)

\subsubsection{Check for bearing}

For compression perpendicular to the grain the condition to be satisfied is: $\sigma_{c, 90, d} \leq f_{c, 90, d} \cdot K_{c, 90}$, Where $\sigma_{\mathrm{c}, 90, \mathrm{~d}}$ is the design compressive stress perpendicular to the grain

$$
\sigma_{\mathrm{c}, 90, \mathrm{~d}}=\frac{\mathrm{F}}{\mathrm{bx}}
$$

Where, $\mathrm{F}$ is the design bearing force, $\mathrm{b}$ is the bearing width, and $x$ is the bearing length. $f_{c, 90, d}$ is the design compressive strength perpendicular to the grain (characteristic bearing strength of the timber) and is defined as:

$$
\mathrm{f}_{\mathrm{c}, 90, \mathrm{~d}}=\frac{\mathrm{f}_{\mathrm{c}, 90, \mathrm{k}} \cdot \mathrm{K}_{\text {mod,med }} \cdot \mathrm{K}_{\mathrm{sys}} \cdot \mathrm{K}_{\mathrm{c}, 90}}{\gamma_{\mathrm{m}}}
$$




\subsubsection{Deflection check}

The condition that must be satisfied is

$$
\omega_{\text {fin }} \leq u_{\text {net,fin }}
$$

Where the terms are as defined in the sizing of deck above.

For two span joist,

Bending deflection

$$
\omega_{\text {fin }}=\frac{\mathrm{wl}^{4}}{185 \mathrm{E}_{0, \text { mean }} \mathrm{I}} \times\left(1+\frac{0.96 \mathrm{E}_{0, \text { mean }} \mathrm{h}}{\mathrm{G}_{0, \text { mean }} \mathrm{l}}\right)
$$

Where all the terms are as defined in equation (1)

\subsection{Design of the Primary Joist}

The procedure for the design of the primary joist is same as that outlined above for the design of the secondary joist. Table 1 gives the input parameters for the design of the two span floor

\subsection{Reliability Analysis of the Timber Floor}

The design procedure for the timber floor subjected to serviceability and ultimate loads is to ensure that;

i) The deflection of floor structural elements do not exceed the deflection limit prescribed in the codes

ii) The design bending strength and shear strength parallel to grain, as well as compression strength perpendicular to grain of structural elements are not reached or exceeded

The limit state functions for the four modes of failure for the structural elements are presented in equations (9) to
Table 1: Input parameters for the design of the timber two

\begin{tabular}{|c|c|}
\hline Parameter (symbol) & Value used \\
\hline Thickness of deck (h) & $12.5 \mathrm{~mm}$ \\
\hline Spacing of secondary joists (I) & $400 \mathrm{~mm}$ \\
\hline Unit weight of D40 (iroko) timber $(\rho)$ & $7.0 \mathrm{kN} / \mathrm{m}^{3}[14]$ \\
\hline Self-weight of timber & $0.082 \mathrm{kN} / \mathrm{m}^{2}$ \\
\hline Services & $0.5 \mathrm{kN} / \mathrm{m}^{2}[14]$ \\
\hline Total permanent action & $0.582 \mathrm{kN} / \mathrm{m}^{2}$ \\
\hline Live load for residential building & $1.5 \mathrm{kN} / \mathrm{m}^{2}[14]$ \\
\hline $\mathrm{E}_{0, \text { mean }}$ & $11 \mathrm{kN} / \mathrm{mm}^{2}[15]$ \\
\hline Breadth of deck (b) & $1000 \mathrm{~mm}$ \\
\hline Span of secondary joists (l) & $3000 \mathrm{~mm}$ \\
\hline Design action on joist at ULS (w) & $1.61 \mathrm{kN} / \mathrm{m}$ \\
\hline Design action on joist at SLS (w) & $0.89 \mathrm{kN} / \mathrm{m}$ \\
\hline Design action on deck at ULS (w) & $3.8 \mathrm{kN} / \mathrm{m}^{2}$ \\
\hline Maximum bendin moment on deck $\left(\mathrm{M}_{\max }\right)$ & $0.33 \mathrm{kNm}$ \\
\hline Shear force on deck (V) & $2.28 \mathrm{kN}$ \\
\hline Design bearing force on deck $(F)$ & $2.28 \mathrm{kN}$ \\
\hline bearing length of deck (x) & $75 \mathrm{~mm}$ \\
\hline Bending strength $\left(\mathrm{f}_{\mathrm{m}, 0, \mathrm{k}}\right)$ & $40 \mathrm{~N} / \mathrm{mm}^{2}[15]$ \\
\hline Shear strength $\left(\mathrm{f}_{\mathrm{v}, 0, \mathrm{k}}\right)$ & $3.8 \mathrm{~N} / \mathrm{mm}^{2}[15]$ \\
\hline Compressive strength $\left(\mathrm{f}_{\mathrm{c}, 90, \mathrm{k}}\right)$ & $8.8 \mathrm{~N} / \mathrm{mm}^{2}[15]$ \\
\hline $\mathrm{M}_{\max }$ on joist $=\mathrm{wl}^{2} / 8$ & $1.82 \mathrm{kNm}$ \\
\hline Shear force on joist, $V=5 \mathrm{wL} / 8$ & $3.04 \mathrm{kN}$ \\
\hline Design bearing force on joist, $F$ & $6.04 \mathrm{kN}$ \\
\hline bearing length of joist, $\mathrm{x}$ & $125 \mathrm{~mm}$ \\
\hline
\end{tabular}
spans floor deck and joist.

(12)

a) Bending

$$
\begin{gathered}
g\left(f_{m, k}, K_{\text {mod }}, K_{s y s}, K_{h}, \gamma_{m}, b, h, M\right)=\frac{f_{m, k} \cdot K_{m o d} \cdot K_{s y s} \cdot K_{h}}{\gamma_{m}}-\frac{6 M}{b h^{2}} \\
M_{\max }=\frac{w l^{2}}{8}, \quad w=\left(\gamma_{G} \alpha+\gamma_{Q}\right) Q_{k}
\end{gathered}
$$

Therefore, $M_{\max }=\frac{\left(\gamma_{G} \alpha+\gamma_{Q}\right) Q_{k} l^{2}}{8}$

$$
g\left(f_{m, k}, K_{m o d}, K_{s y s}, K_{h}, \gamma_{m}, b, h\right)=\frac{f_{m, k} \cdot K_{m o d} \cdot K_{s y s} \cdot K_{h}}{\gamma_{m}}-\frac{3\left(\gamma_{G} \alpha+\gamma_{Q}\right) Q_{k} l^{2}}{4 b h^{2}}
$$

b) Shear

$$
g\left(f_{y, k}, K_{m o d}, K_{s y s}, \gamma_{m}, b, h, V\right)=\frac{f_{y, k} \cdot K_{m o d} \cdot K_{s y s}}{\gamma_{m}}-\frac{15\left(\gamma_{G} \alpha+\gamma_{Q}\right) Q_{k} l}{16 b h}
$$

c) Bearing

d) Deflection

$$
g\left(f_{c, 90, k}, K_{m o d}, K_{s y s}, \gamma_{m}, b, x, F_{d}\right)=\frac{f_{c, 90, k} \cdot K_{m o d} \cdot K_{s y s}}{\gamma_{m}}-\frac{5\left(\gamma_{G} \alpha+\gamma_{Q}\right) Q_{k} l}{4 b x}
$$

$$
g\left(w, l, b, h, E_{0, \text { mean }}, G_{0, \text { mean }}, \mathrm{I}\right)=\frac{l}{250}-\frac{(\alpha+1) Q_{k} l^{4}}{185 E_{0, \text { mean }} I} \times\left(1+\frac{0.96 E_{0, \text { mean }} h}{G_{0, \text { mean }} l}\right)
$$

Where $\propto=\frac{G_{k}}{Q_{k}}$ is dead-live load ratio, $f_{m, 0, k}$ is characteristic bending strength parallel to grain, $k_{\text {mod }}$ is modification factor for load duration and moisture content to take care of variation in load duration and moisture content, $\mathrm{k}_{\text {sys }}$ is system strength factor, $\gamma_{m}$ is partial factor or coefficient for material properties, $b$ is the breadth of the floor element, $h$ is the depth of the floor element, $\mathrm{f}_{\mathrm{v}, 0, \mathrm{k}}$ is characteristic shear strength of timber parallel to grain, $\mathrm{k}_{\mathrm{h}}$ is depth factor, $\mathrm{f}_{\mathrm{c}, 90, \mathrm{k}}$ is characteristic compressive strength of timber perpendicular to grain, $E_{0 \text {,mean }}$ is modulus of elasticity and $G_{0 \text {,mean }}$ is shear modulus. 
The results obtained from the deterministic design of the timber floor were used to carry out a reliability analysis of the floor using FORM5[13]. FORM5[13]is a Software written in FORTRAN77 based on first order reliability method, used to estimate the safety index $(\beta)$ or probability of failure $\left(\mathrm{P}_{\mathrm{f}}\right)$ of structures. Table 2 shows the stochastic variables with their probability distributions and statistical parameters used in the reliability analysis of the floor for the four modes of failure.

\subsection{First Order Reliability Method (Form)}

FORM is an analytical approximation in which the reliability index is interpreted as the minimum distance from the origin to the limit state surface in standardized normal space (u-space) and the most likely failure point (design point) is searched using mathematical programming methods. Because the performance function is approximated by a linear function in the sample space at the design point, accuracy problems occur when the performance function is strongly nonlinear [17]

In the special cases where the failure surface is linear and all basic variables are normally distributed it is easy to show that there is a direct relation between the failure probability $\left(\mathrm{P}_{\mathrm{f}}\right)$ and reliability index $(\beta)$. That is;

$$
P_{f}=\Phi(-\beta) \Leftrightarrow \beta=-\Phi^{-1}\left(P_{f}\right)
$$

In (14) $\Phi$ is the standardized normal distribution function. In general, the failure surface is non-linear, and the basic variables non-normal. The generalized reliability index $\beta_{\mathrm{g}}$ can be defined by:

$$
\beta_{g}=\Phi^{-1}\left(P_{f}\right)
$$

The reliability is the compliment of the probability of failure; $1-\mathrm{P}_{\mathrm{f}}$.

\section{RESULTS AND DISCUSSION}

\subsection{Deterministic Design of the two Spans Timber Floor to} Eurocode 5

The two spans floor was analyzed and designed using deterministic approach and results are shown in Table 3. The results showed that the applied stresses for bending, shear and bearing of members were far less than the design strengths, except for the primary joist. Deflections due to applied load on members were less than the permissible deflection. Therefore, a $12.5 \mathrm{~mm}$ timber deck, $75 \mathrm{~mm}$ x $125 \mathrm{~mm}$ secondary joist and $125 \mathrm{~mm} \times$ $200 \mathrm{~mm}$ primary joist section of strength class D40 meet the ultimate limit state and serviceability limit state requirements based on provision in [12].

\subsection{Reliability Assessment}

\subsubsection{Effect of Variation of Dead to Live Load Ratio on Safety Indices}

Results of the reliability assessment of the timber floor deck at varying dead/live load ratio is shown in Figure 2, and shows that the design of the timber floor deck is seemingly conservative for the four modes of failure when compared with the recommended target safety indices of 3.8 and 1.5 for ultimate limit sate and serviceability limit state, respectively for moderate consequences of failure [16]. It was observed that the safety indices decreased with increase in load ratio values for all the modes of failure. It was also noted that failure in bearing had the least conservative safety indices.

Figure 3 and 4 shows the variation of safety index with load ratio for the secondary and primary joists, respectively in the two span timber floor. There was a general decrease in safety index of the joists with increase in load ratio.

\begin{tabular}{|c|c|c|c|c|}
\hline $\mathrm{S} / \mathrm{N}$ & Variables & Meaning & Probability distribution & Covariance \\
\hline 1 & $\mathrm{f}_{\mathrm{m}, \mathrm{k}}$ & Characteristic bending strength // to grain $\left(\mathrm{N} / \mathrm{mm}^{2}\right)$ & Lognormal & 0.15 \\
\hline 2 & $\mathrm{f}_{\mathrm{v}, \mathrm{k}}$ & Characteristic shear strength $\left(\mathrm{N} / \mathrm{mm}^{2}\right)$ & Lognormal & 0.15 \\
\hline 3 & $\mathrm{f}_{\mathrm{c}, 90, \mathrm{k}}$ & $\begin{array}{l}\text { Characteristic compressive strength perp. to } \\
\text { grain }\left(\mathrm{N} / \mathrm{mm}^{2}\right)\end{array}$ & Lognormal & 0.15 \\
\hline 4 & $\mathrm{Q}_{\mathrm{k}}$ & Imposed load $(\mathrm{N} / \mathrm{mm})$ & Gumbel & 0.30 \\
\hline 5 & $B$ & Width $(\mathrm{mm})$ & Normal & 0.01 \\
\hline 6 & $H$ & Depth $(\mathrm{mm})$ & Normal & 0.01 \\
\hline 7 & $L$ & Length (mm) & Normal & 0.01 \\
\hline 8 & $X$ & Bearing Length (mm) & Normal & 0.01 \\
\hline 9 & $\mathrm{E}_{0, \text { mean }}$ & Modulus of elasticity $\left(\mathrm{N} / \mathrm{mm}^{2}\right)$ & Log Normal & 0.13 \\
\hline 10 & I & Moment of inertia $\left(\mathrm{mm}^{4}\right)$ & Log Normal & 0.01 \\
\hline 11 & $\mathrm{G}_{0, \text { mean }}$ & Shear modulus $\left(\mathrm{N} / \mathrm{mm}^{2}\right)$ & Log Normal & 0.01 \\
\hline
\end{tabular}

Table 2: Stochastic variables and statistical parameters

Source: [16]: $\gamma_{\mathrm{m}}=1.3, \mathrm{k}_{\bmod }=0.8, \mathrm{k}_{\mathrm{sys}}=1, \mathrm{k}_{\mathrm{h}}=1.08, \alpha=0.2,0.4,0.6,0.8,1.0$ 
Table 3: Summary of deterministic design of the two span timber floor

\begin{tabular}{|c|c|c|c|}
\hline Parameter & Deck & $\begin{array}{c}\text { Secondary } \\
\text { Joist }\end{array}$ & $\begin{array}{c}\text { Primary } \\
\text { Joist }\end{array}$ \\
\hline Depth (mm) & 12.5 & 125 & 200 \\
\hline Breadth (mm) & 1000 & 75 & 125 \\
\hline Span (mm) & 400 & 3000 & 3600 \\
\hline $\begin{array}{l}\text { Bending } \\
\text { stress }\left(\mathrm{N} / \mathrm{mm}^{2}\right)\end{array}$ & 12.55 & 9.30 & 24.23 \\
\hline $\begin{array}{l}\text { Bending } \\
\text { strength }\left(\mathrm{N} / \mathrm{mm}^{2}\right)\end{array}$ & 26.58 & 24.61 & 24.62 \\
\hline Shear stress $\left(\mathrm{N} / \mathrm{mm}^{2}\right)$ & 0.27 & 0.49 & 1.68 \\
\hline $\begin{array}{l}\text { Shear } \\
\text { strength }\left(\mathrm{N} / \mathrm{mm}^{2}\right)\end{array}$ & 2.30 & 2.30 & 2.30 \\
\hline $\begin{array}{l}\text { Bearing } \\
\text { stress }\left(\mathrm{N} / \mathrm{mm}^{2}\right)\end{array}$ & 0.03 & 0.64 & 2.99 \\
\hline $\begin{array}{l}\text { Bearing } \\
\text { strength }\left(\mathrm{N} / \mathrm{mm}^{2}\right)\end{array}$ & 5.42 & 5.42 & 5.42 \\
\hline $\begin{array}{l}\text { Actual deflection } \\
(\mathrm{mm})\end{array}$ & 0.21 & 4.74 & 12.55 \\
\hline Permissible deflection & 1.60 & 12.00 & 14.40 \\
\hline
\end{tabular}

The primary joists had safety indices in shear and bending of 1.2 to 2.8 with decrease in dead to live load ratio and were below the recommended safety index of 3.8 specified in JCSS [16]. It was also observed that

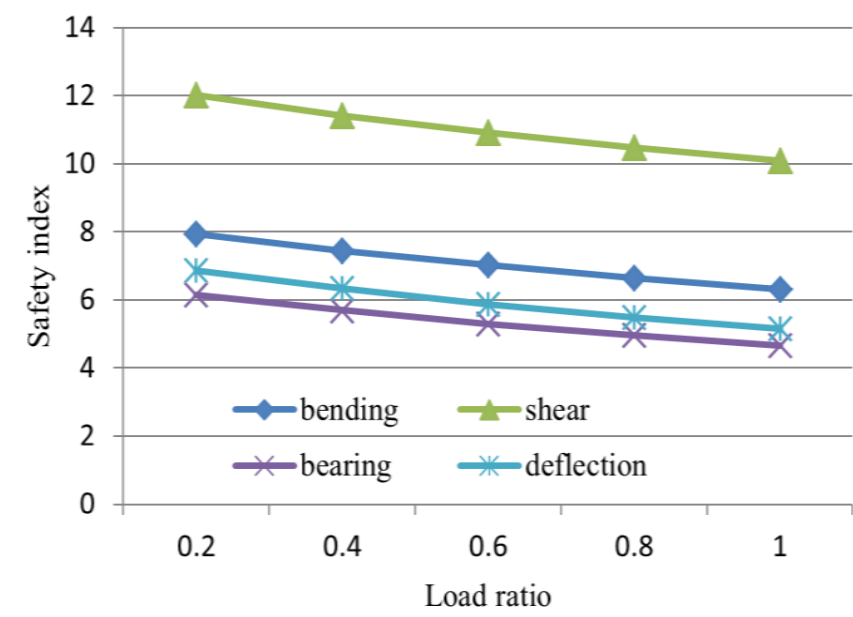

Figure 2: Reliability assessment of the timber floor deck

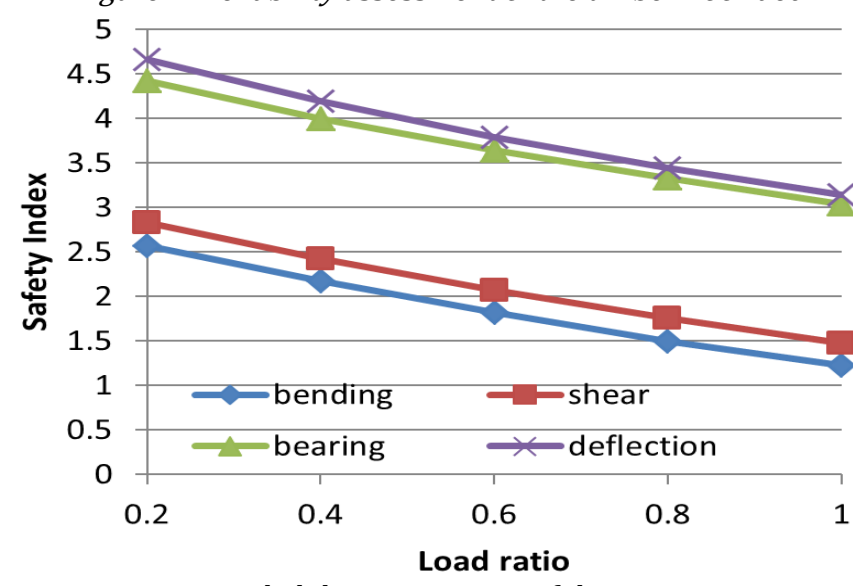

Figure 4: Reliability assessment of the primary joists bending was the most critical mode of failure. The results also indicate that the primary joists have higher probability of failure than the secondary joists.

\subsubsection{Effect of Variation of Depth of Deck and Depth of Joist on Safety Index}

There was a general increase in safety indices of the three mode of failure as the depth of the timber floor deck was increased from $12.5 \mathrm{~mm}$ to $15 \mathrm{~mm}$ as shown in Figure 5. It was also noted that there was general decrease in safety indices as the depth of the floor deck was decreased from $12.5 \mathrm{~mm}$ to $5 \mathrm{~mm}$. There was a sharp drop in safety indices for the depth of floor deck less than $10 \mathrm{~mm}$. This could be attributed to reduction in the flexural rigidity values (EI) of the floor deck. It was also noted that at higher depth of timber floor deck, the deck may be reliable but not economical, consistent with [3]. However, there is the need to recognize the balance between safety consideration and economy by use of appropriate factors of safety, as noted in [18]. In the case of variation of primary joist depth, there was increase in safety indices as depth increased from $125 \mathrm{~mm}$ to 225 $\mathrm{mm}$ as shown in Figure 6. But the increase is more pronounced in deflection followed by the bending.

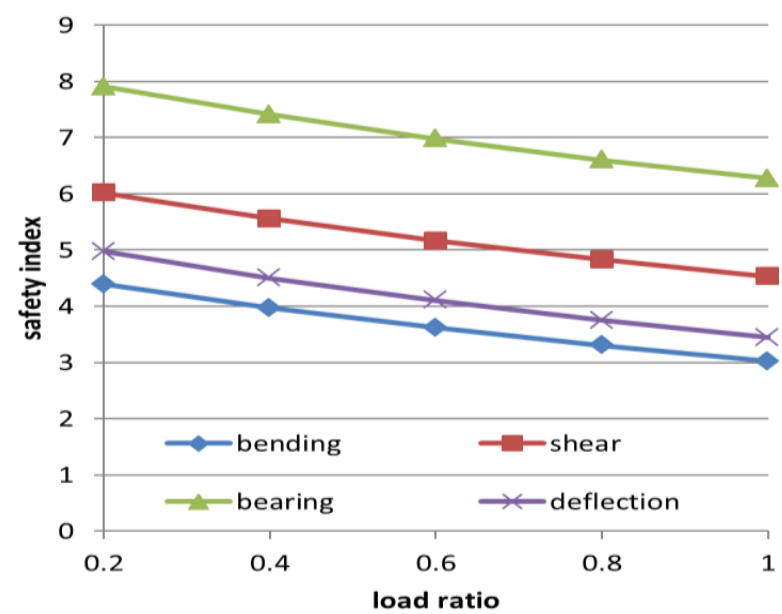

Figure 3: Reliability assessment of the secondary joists

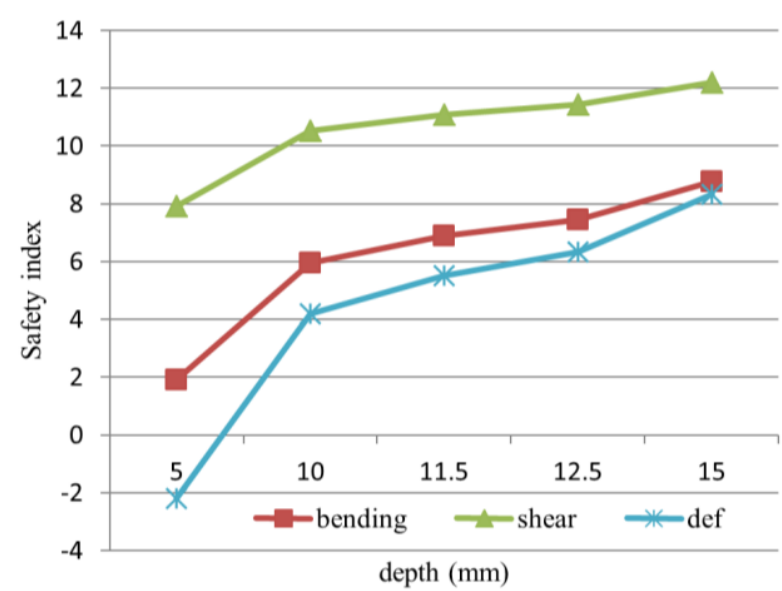

Figure 5: Safety index versus depth for the deck

Vol. 36, No. 1, January 2017 
This shows that the depth is critical to bending and deflection than to shear and bearing. The primary joist seemed safe in bending when the depth was increased from $200 \mathrm{~mm}$ to $225 \mathrm{~mm}$.

\subsubsection{Effect of Variation of Span of The Floor Deck and Span of Joist on Safety Index}

The variation of span of floor deck shown in Figure 7, indicated decrease in safety indices for all modes of failure as the span was increased from $300 \mathrm{~mm}$ to 500 $\mathrm{mm}$. However, the timber floor deck was reliable even at span of $500 \mathrm{~mm}$. It was also noted that bending and deflection are more affected than the shear and bearing modes of failure. Increasing the span of primary floor joist from $2500 \mathrm{~mm}$ to $4500 \mathrm{~mm}$ decreased the safety indices for all modes of failure, as shown in Figure 8. Deflection and bending are more sensitive to change in span than shear and bearing. This is because increase in span implies increase in bending moment and increase in deflection of floor joist.

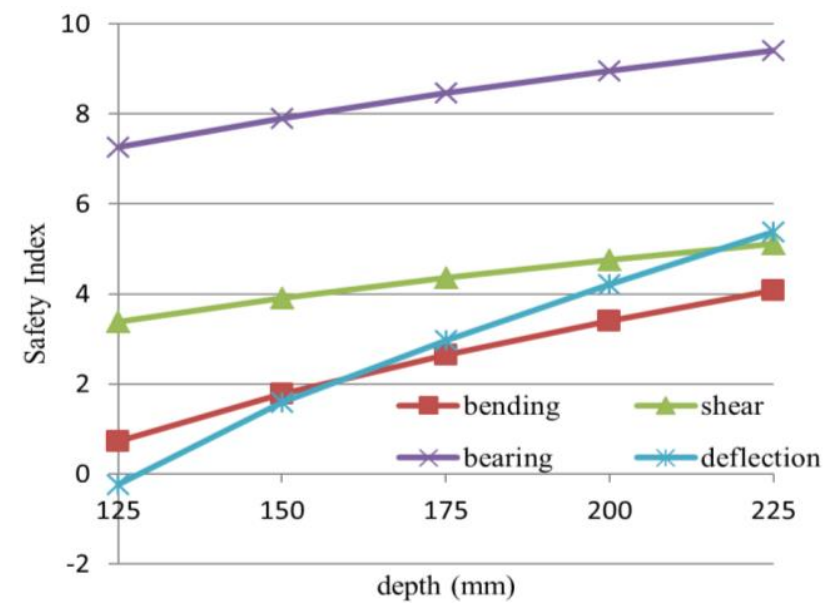

Figure 6: Variation of safety index with depth of the primary joist

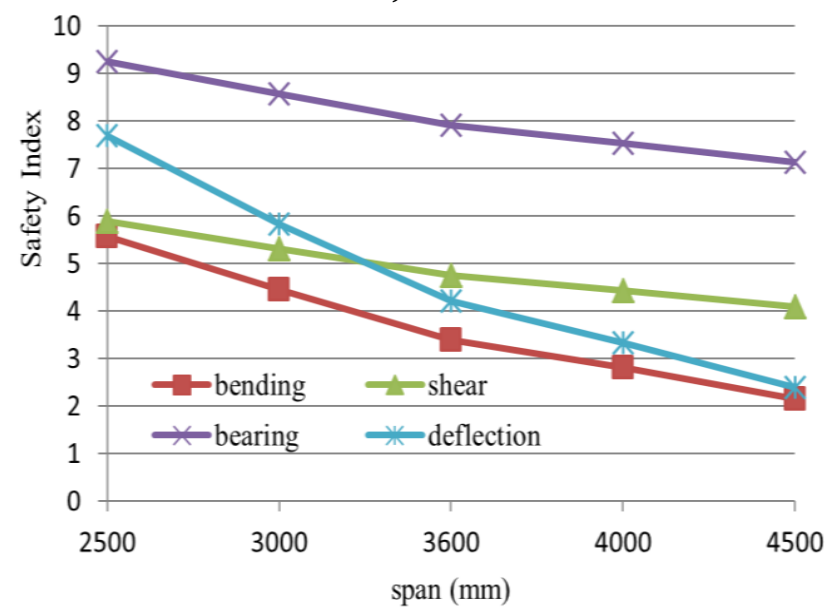

Figure 8: Variation of safety index with span of the primary joist

\subsubsection{Effect of Variation of Breadth of the Primary Joist on Safety Index}

There was general and consistent increase in safety indices as the breadth of primary floor joist increased from $100 \mathrm{~mm}$ to $200 \mathrm{~mm}$ as shown in Figure 9. This could be attributed to increase in EI values, with attendant increase in rigidity of joist. Bending was the most critical mode of failure, and the primary joist seemed safe at breadth of section of $175 \mathrm{~mm}$ and above.

\section{CONCLUSIONS}

The following conclusions were drawn from the deterministic and stochastic analysis carried out on the two span floor

i) The deterministic design shows that the design is satisfactory as limiting stresses and deflection were not exceeded.

ii) The primary floor joists had safety indices in shear and bending of 1.2 to 2.8 with decrease in dead to live load ratio and were below the recommended safety index of 3.8 specified in JCSS

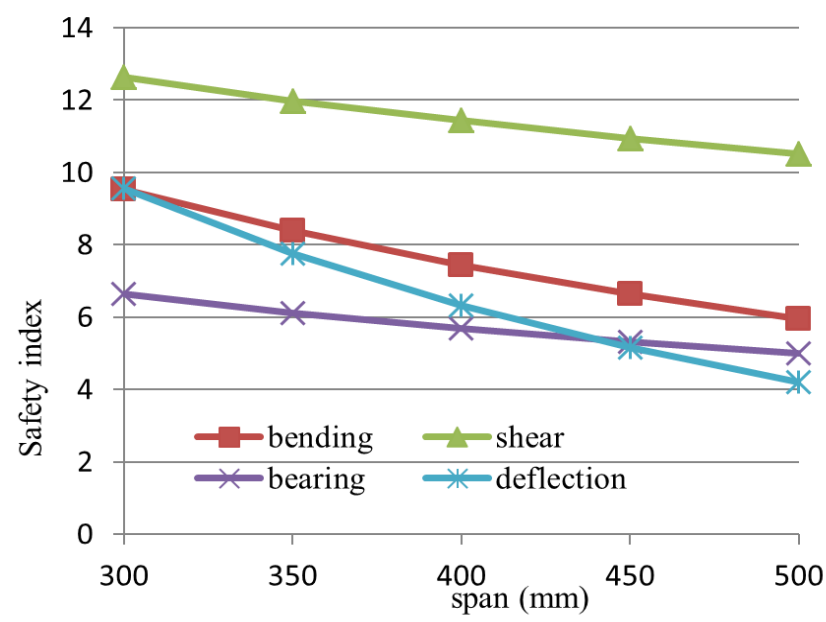

Figure 7: Safety index versus span of the deck

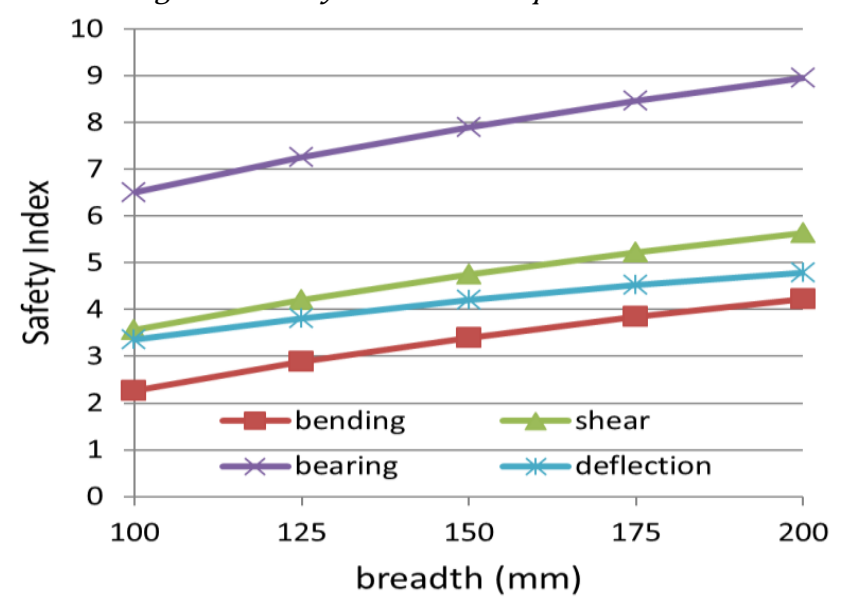

Figure 9: Variation of safety index with breadth of the primary joist section 
iii) The timber floor structural elements are more reliable in bearing, shear and deflection and critical in bending mode.

iv) The section depth and span of floor elements are more sensitive in bending and deflection modes than shear and bearing modes.

\section{REFERENCES}

[1] Thomas, G. W. APA Engineered Wood Handbook, McGraw-Hill, London, 2002.

[2] Sousa, H., Sørensen J. D., Kirkegaard P. H. Reliability analysis of timber structures through NDT data upgrading, Short Term Scientific Mission, COST E55 Action, ISSN 1901-726X, DCE Technical Report No. 96, 2010

[3] Aguwa, J. I. and Sadiku, S. "Reliability studies on the Nigerian Ekki timber as bridge beam in bending under the ultimate limit state of loading", Journal of Civil Engineering and Construction Technology, vol.2, Number 11, 2011, pp 253-259

[4] Aguwa, J. I. "Reliability assessment of the Nigerian Apa (Afzelia Bipindensis) timber bridge beam Subjected to bending and deflection under the ultimate limit state of loading", International Journal of Engineering and Technology, vol. 2, Number 6, , pp 1076-1088, 2012.

[5] Porteous, J. and Kermani, A. Structural Timber Design to Eurocode 5, Blackwell Science Ltd, a Blackwell Publishing company, Oxford, 2007.

[6] Karlsen, G. and Slitskouhov, Y.U. Wooden and Plastic Structures, First edition, Mir Publishers, Moscow, , pp. 4001989.

[7] Afolayan, J. O. and Adeyeye, A. "Failure Analysis of a GlueJointed Roof Truss", Journal of Engineering and Applied Science, vol. 17, Number 1, pp 51-63 1998.

[8] The landersson, S. Introduction: Safety and Serviceability in Timber Engineering. In The landersson, S. and Larsen H.J. (Eds) Timber Engineering, John Wiley and Sons Ltd,
The Atrium, Southern Gate, Chichester, West Sussex, England, pp. 2442003.

[9] Afolayan, J. 0. and Abubakar, I. "Reliability Analysis of Reinforced Concrete One-way Slabs: The Ultimate Conditions", Nigerian Journal of Engineering, Vol. 11, Number 2, pp 28 - 31. 2003.

[10] Oriola, F.O.P., Moses, G. and Afolayan, J. O. "Reliability Estimates of Field Hydraulic Conductivity of Compacted Bagasse Ash Treated Foundry Sand", Journal of Environment and Earth Science, vol. 2, Number 6, , pp 112. 2012.

[11] Abubakar, I. "Reliability Analysis of Structural Design Parameters of Strip Footings", Journal of Applied Science and Research, vol. 2, Number 7, pp 397-401. 2006.

[12] BS EN -1-1: Eurocode 5: Design of Timber Structures, Part 1-1. General - Common Rules and Rules for Buildings, British Standard Institution, London, 2004. 1995.

[13] Gollwitzer, S., Addo, T. and Rachwitz, R. First Order Reliability Method (FORM) User's manual, Munich, Germany, 1988.

[14] BS EN 1991-1-1: Eurocode 1: Actions on Structures, Part 1-1. General Actions - Densities, Self-weight, Imposed Loads for Buildings, British Standard Institution, London, 2002.

[15] BS EN 384: Structural timber: Determination of characteristic values of mechanical properties and density, British Standard Institution, London, 2010.

[16] JCSS: Probabilistic Model Code, Part 3. Resistance Models: Properties of Timber, Joint Committee on Structural Safety, 2002, http://www.jcss.ethz.ch, access on 31 st May 2014.

[17] Melchers R. E. Structural Reliability Analysis and Prediction, Ellis Horwood Limited, Great Britain, 1999.

[18] Afolayan, J.O. "Inequality Problems and their Applications in Structural Safety", Journal of Engineering and Applied Science, Vol. 2, 1995, pp 11-14. 